УДК 39:502.22](477)

\section{Цитування:}

Tsoi $\mathrm{T}$. The role of environmental and ethnic experience in the culture of natural use as a factor of the national self-identification of the Ukrainian people [Роль екологічного та етнічного досвіду в культурі природокористування як чиннику національної самоідентифікації українського народу]. Вісник Національної академії керівних кадрів культури і мистеитв : наук. журнал. №2. Київ : ІДЕЯ ПРИНТ, 2020. С. 48-51.

Tsoi T. (2020). The role of environmental and ethnic experience in the culture of natural use as a factor of the national self-identification of the Ukrainian people. National Academy of Culture and Arts Management Herald: Science journal, 2, 48-51 [in Ukrainian].

\author{
Tsoi Tetiana, \\ Ph.D. in Philosophy, \\ Senior Lecturer of the \\ National Academy of Fine Arts and Architecture \\ ORCID: https://orcid.org/0000-0003-4413-1478 \\ tatianatsoy11@gmail.com
}

\title{
THE ROLE OF ENVIRONMENTAL AND ETHNIC EXPERIENCE IN THE CULTURE OF NATURAL USE AS A FACTOR OF THE NATIONAL SELF-IDENTIFICATION OF THE UKRAINIAN PEOPLE
}

The purpose of the article is to determine the role of ecological and ethnic experience in the culture of the natural resources of the Ukrainian people for the formation of the modern ecological culture of the nation. The methodology is based on the interdisciplinary integration of philosophy, ecology, ethics, and cultural studies. The scientific novelty is determined by the relevance of comprehension of the intersection of "ethnic" and "ecological" for the formation of the modern ecological culture of Ukrainian society, which is a significant factor of national self-identification. Conclusions Involvement of the traditional ecological and ethnic experience of the individual people is an important factor for its further development since one of the essential indicators of the stability of the development of national culture should be the ethnic and ecological orientation, that is, the use of ethnic and ecological traditions, on the basis of which innovative processes can be built up and go to the future. In order to adequately perceive the provisions of universal macroethics, it is necessary to take into account environmental principles and in practice take into account the meanings laid down in our spiritual tradition. It is important to realize not only the need to engage in the global civilizational space but also to anticipate the risks involved in such inclusion. Not least last, it's about national self-identification as a counteraction to global unification.

Key words: ecological and ethnic experience, ecological culture, ethnos, national identity, universal macroethics.

Цой Тетяна Василівна, кандидат філософських наук, стариий викладач Начіональної академії образотворчого мистеитва і архітектури

Роль екологічного та етнічного досвіду в культурі природокористування як чиннику національної самоідентифікації українського народу

Метою статті $\epsilon$ визначення ролі екологічного та етнічного досвіду в культурі природокористування українського народу для формування сучасної екологічної культури нації. Методологія дослідження побудована на міждисциплінарному інтегруванні методів філософії, екології, етики та культурології. Наукова новизна визначається актуальністю осмислення перетину «екологічного» та «етнічного» для формування сучасної екологічної культури українського суспільства, що є вагомим чинником національної самоідентифікації. Висновки. Залучення традиційного екологічного та етнічного досвіду окремого народу є важливим чинником для подальшого його поступу, оскільки одним із сутнісних показників стабільності розвитку національної культури має бути етно-екологічна спрямованість, тобто використання етнічних та екологічних традиції, на основі яких можна вибудовувати інноваційні процеси і прямувати в майбутнє. Для адекватного сприйняття положень універсальної макроетики, необхідно врахувати екологічні принципи, та на практиці реалізувати смисли, закладені в нашій духовній традиції. Важливо усвідомлювати не лише необхідність включитися в глобальний цивілізаційний простір, а й передбачити ті ризики, що несе в собі таке включення. Не в останню чергу мова йде про національну самоідентифікацію як про протидію глобальній уніфікації.

Ключові слова: екологічний та етнічний досвід, екологічна культура, етнос, національна самоідентифікація, універсальна макроетика.

(C)Tsoi T., 2020 


\title{
Вісник Національної академії керівних кадрів культури і мистецтв № 2'2о20
}

\begin{abstract}
Цой Татьяна Васильевна, кандидат философских наук, старший преподаватель Наииональной академии изобразительного искусства и архитектуры

Роль экологического и этнического опыта в культуре природоиспользования как фактора национальной самоидентификации украинского народа

Целью статьи является определение роли экологического и этнического опыта в культуре природоиспользования украинского народа для формирования современной экологической культуры нации. Методология исследования построена на междисциплинарном интегрировании методов философии, экологии, этики и культурологии. Научная новизна определяется актуальностью осмысления пересечения «экологического» и «этнического» для формирования современной экологической культуры украинского общества, что является весовым фактором национальной самоидентификации. Выводы. Приобщение традиционного экологического и этнического опыта отдельного народа является важным фактором для дальнейшей его поступи, поскольку одним из существенных показателей стабильности развития национальной культуры должна бать этно-экологическая направленность, т.е. использование этнических и экологических традиций, на основе которых можна построить инновационные процессы и двигаться в будущее. Для адекватного восприятия основных положений универсальной макроэтики, необходимо учесть экологические принципы, и на практике реализовать смыслы, заключенные в нашей духовной традиции. Важно осознавать не только необходимость включения в глобальное информационное пространство, а и предусмотреть те риски, которые несет в себе такое включение. Не в последнюю очередь речь идет про национальную самоидентификацию как противодействие глобальной унификации.
\end{abstract}

Ключевые слова: экологический и этнический опыт, экологическая культура, этнос, национальная самоидентификация, универсальная макроэтика.

The actuality of Research. Each national culture consists of many components, which, despite all the diversity and apparent dissociation, are synthesized into organic and sufficiently dynamic integrity that objectively and convincingly characterizes a certain historical community of people with all its specific manifestations. Nowadays more and more attention of researchers is attracted by the ecological aspects of national cultures, in particular the relation between their eco-phile and eco-phobic elements. The mentioned elements correlate with each other and to a large extent determine their own (personal) "physiognomy" of the nation and even determine its further fate. Moreover, in the context of environmental analysis, complex, sometimes elusive for other approaches, the signs of a concrete national culture in the whole range of its manifestations of substantive and spiritual. And this also applies to retrospectives, and the present state, and futurological tendencies of further development.

The state of scientific development. The study of L. Gumilev [1], I. Zabelin [7], I. Krut [7], and others is of great importance in understanding the traditions of nature use and their consolidation in the national culture. Among the domestic scientists, the problems of the formation of certain ethical principles in relations with the natural environment are devoted to the works of T. Abolina [4], O. Kyselyova [4], A. Yermolenko [5], S. Grabovsky [3], O. Stegnia [3], F. Canaka [8], L. Yurchenko [9], . T. Gardashuk [2]. At the same time, a holistic study of the synthesis of the ethnic and ecological experience of the people with the principles of modern universal ethics in the context of national self-identification remains relevant and needs further in-depth study.

The purpose of the article is to determine the role of ecological and ethnic experience in the culture of the natural resources of the Ukrainian people and the application of a traditional respectful moral attitude towards nature for the formation of a modern ecological culture of a nation.

Presenting the main material. Studies of ethnographers prove that the area in which a certain ethnic group lives is one of the most important conditions for the formation of the people since its adaptation to the natural environment provides future civilization achievements. This thesis goes well beyond the traditional geopolitical constructions, which are now widely used in political science. It is about the organic affinity of the population and the landscape and the ethnic group. The biological adaptation of man to the natural environment, the landscape in which the history of the people took place (which gives grounds for the term "organic patriotism") is an extremely important factor for an adequate self-identification of one or another nation (ethnos). It turns out that there are more analogies than differences between the processes of biological and social evolution. In the West, such a social movement, as bioregionalism, which is transforming into a separate scientific direction, has emerged and becomes more active. His representatives advocate the principle of attachment of human life to a certain territory. A bioregional society (a constantly evolving society on the same territory) has significant advantages: its representatives feel "rooted" where they were born, where their ancestors lived from time immemorial. The most optimal natural and social conditions of life they find in their homeland. Representatives of such a society will not provide their livelihoods at the expense of reckless destructive exploitation of land and its organic world. Depth ecologists consider bioregionalism as an ideal political organization of society, based on a sense of 
belonging to a particular natural environment, the unique differences of a certain territory. The concept of bioregionalism is oriented on providing a clear cultural-ethnic matrix within which the only one can easily and organically exist $[2,59]$

Historical development of the Ukrainian community demonstrates the traditional priority of nature as a base value. Of course, this is connected with agriculture - the symbol and meaning of our culture and our way of life. Communicating with nature through organic inclusion in natural cycles was one of the highest values of the Ukrainian ethnos. It was with his native land, the environment, whose love was instilled with the mother's milk, linked our traditional virtues: heroism, devotion to his land, and his own land, household ownership. Such an attitude to their own traditional culture was passed from generation to generation through the mechanisms of social education, established through oral folk art, and later - through Ukrainian classical literature. Nature did not act as a background against which events unfolded - it has always been an active person. Earth and love for it have become an outstanding feature of our mentality.

It is from here that the specialists draw the typical features of the national character: a subtle sense of harmony of the environment, hard work, patience, soft humor, lyricalness, a sense of the master and a certain individualism (awareness of the self-worth of one's own personality), a sense of justice that prompts continuous searches for the truth $[8$, 155]. Agriculture is an extremely complex formation. It made it possible to obtain not only daily bread but also spiritual bread. Such an attitude to the earth, the ability to enjoy labor life, the enchantment of nature, the intimate connection of the Ukrainian peasant with her makes a well-known appeal to "subjugation of nature" absurd for national consciousness, inorganic, even anti-ethnic. Here, it seems, we are dealing with the undeniable eco-philosophical feature of Ukrainian character, which is not typical of the European (Faustian) man. The emotional and sensual nature of Ukrainian is more characteristic of not "confrontation", but rather the observance of the laws of nature, an intuitive penetration into the essence of its processes. The experience of such communication with nature and is the basis of his spiritual culture.

The moral principles formed on this ground were not external norms of behavior, but a kind of internal imperative of existence. In particular, the idea of good and evil was inspired by the natural environment and labor, and in its content and meaning went beyond the limits of ethics itself. They played the role of ideological landmarks, which held the complex structure of the "superstructure" of the ethnic group. In addition, the ethical and aesthetic components of the Ukrainian agricultural cult were uniquely organically combined. Morality, practicality, and beauty were indivisible in the perception of our ancestors.

It was in the rites of the agricultural cult that the vast majority of traditional (ethnic) Ukrainian values were formed, the main of which was "native land" and nature. As A. Yermolenko notes: "... it seems that the return to the primary value of ethos would indicate the path to new ethics that would make sense not only for the relations of people with each other but also with their relation to the environment" $[6,199]$. Y. Hargrove, one of the leading ideologues of environmental ethics, noticed that there really is a need not for the "universal ecological ethics, but rather for the whole group of ethics that can take into account national and cultural differentiation. Moreover, any environmental ethics should be considered in the context of local realities, that is, taking into account local geographic features and culture "[10, 229]. It is the search for their own value bases, the conversion to their "native" tradition simplifies the possibility of incorporating them into real moral practice. In our opinion, the very abandonment of traditional morality and the imposition of alien "western" values is one of the main causes of our environmental problems.

The problem of self-identification for our country, as well as for most third-world countries, appears in the quest for participation in a world that has undergone a completely different path of cultural tradition, with radically different from Ukrainian values, models and methods of social education. We lose and destroy our own tradition by engaging in the values of others to us. With that value of culture, which itself is experiencing difficult moments of its identification. Placed from the outside, with the instability of our own spiritual reference points, the values of modern technologized West reject the moral principles of our society far back. Instead, the Ukrainian tradition can become the basis on which the traditional "eco-phile" can be established in the long run. At present, the ecological culture can not base on the tradition of the population of a careful attitude to nature, generated by ethnic experience. Of course, given the planetary context of the environmental problem, humanity, through global dialogue, has to agree on the fundamental ethical principles of coexistence and survival, such as justice, reciprocity, solidarity between individuals and peoples, respect for the human person, etc. These coherent moral principles must precede economics, politics, and law. It has been with this purpose since 1993 that international conferences are being held regularly, discussing the need for the development and adoption of a Global Declaration of Global Ethics, in which peoples of the world must confirm their agreement on the fundamental issues of good 


\section{Вісник Національної академії керівних кадрів культури і мистецтв № 2'2о20}

and evil in the context of preserving life in today's world and in the future.

Modern communicative ethics seeks to substantiate moral membership within a universalist perspective. Representatives of this trend build a model of a universal value system in which the imperatives of "justice" and "co-responsibility" are proposed as regulatory principles that correlate with " an ideal communicative community ". On this basis, A. Yermolenko notes, "moral and ethical norms and values should be based not only on existing existence and the necessity of preservation but also contain absolute dimensions of human existence" [5, 140]. As for solving the ecological problem in the context of our Ukrainian culture, this transforms into the necessity of solving, first of all, the spiritual crisis, namely the discovery of mechanisms of national selfidentification. In order not to dissolve in the global unified, almost quasi-sociocultural space, we need to make ourselves aware of Ukrainians. Our national agrarian culture left us a legacy of a complex of "ecological values", among which the most important is the love of our native land and nature. Ukrainians, especially modern ones, are not a solid peasant world, although much depends on it when we strive for a revival, spiritual uplift, we must attract and use the valuable values that have been gained by the people in the past: its ethnic culture, environmental experience, customs, and so on. Ignoring the achievements of the past, our historical roots are as dangerous as their mythologization.

Conclusions. Involvement of the traditional ecological and ethnic experience of the individual people is an important factor for its further development since one of the essential indicators of the stability of the development of national culture should be the ethnic and ecological orientation, that is, the use of ethnic and ecological traditions, on the basis of which innovative processes can be built up and go to the future. In order to adequately perceive the provisions of universal macroethics, it is necessary to take into account environmental principles and in practice take into account the meanings laid down in our spiritual tradition. It is important to realize not only the need to engage in the global civilizational space but also to anticipate the risks involved in such inclusion. Not least last, it's about national self-identification as a counteraction to global unification.

\section{Jimepamypa}

1. Гумилев Л. Н. Этногенез и биосфера Земли. Москва : Ин-т ДИ - ДИК, 1997. 611 с.

2. Екологічні виміри глобалізації: монографія. Київ : ПАРАПАН, 2006.

$259 \mathrm{c}$.
3. Етнічність. Культура. Історія. Соціальнофілософські нариси. Київ : Ніжин : Видавець ПП Лисенко М.М., 2019. 272 c.

4. Етос i мораль у сучасному світі. Київ : ПАРАПАН, 2004. $200 \mathrm{c}$.

5. Єрмоленко А.М. Екологічна етика: проблеми обгрунтування // Практична філософія. 2003. №3. С. $133-147$.

6. Єрмоленко А. М. Комунікативна практична філософія. Київ : Лібра, 1999. 488 с.

7. Круть И. В., Забелин И.М. Очерки истории представлений о взаимоотношении природы и общества. Москва : Наука, 1988. 416 с.

8. Національне буття серед екологічних реалій: монографія. Київ :Тандем, 2000.318 с.

9. Юрченко Л.І. Екологічна культура в контексті екологічної безпеки. Київ : ПАРАПАН, 2008. 296 с.

10. Hargrove E. Foundations of environmental ethics, New Jersey: Prentice Hall, 1988. 229 p.

\section{References}

1. Gumilev, L.N. (1997). Ethnogenesis and biosphere of the Earth. Moscow: Institute of the DI - DIK [in Russian].

2. Environmental dimensions of globalization. (2006). Kyiv: PARAPAN [in Ukrainian].

3. Ethnicity. Culture. History. Social philosophy Essay. (2006). Kyiv.: Nizhyn: Vudavets PP Lysenko M.M [in Ukrainian].

4. Ethos and morality in the modern world. (2004). Kyiv: PARAPAN [in Ukrainian].

5. Yermolenko, A.M. (2003). Environmental ethics: problems of substantiation. Praktychna filosofiia. 3, 133147 [in Ukrainian].

6. Yermolenko, A.M. (2000). Communicative Practical Philosophy. Kyiv: Libra [in Ukrainian].

7. Krut, I.V., Zabelin, I.M. (1988). Essays on the history of ideas about the relationship between nature and society. Moskva: Nauka [in Russian].

8. National being among ecological realities: a monograph. (2000). Kyiv: Tandem [in Ukrainian].

9. Yurchenko, L.I. (2008). Ecological culture in the context of ecological safety. Kyiv: PARAPAN [in Ukrainian].

10. Hargrove E. Foundations of environmental ethics, New Jersey: Prentice-Hall, 1988. 229 p.

Стаття надійшла до редакиії 16.01.2020 Прийнято до друку 17.02.2020 